\title{
Sustainable Development Strategy for Russian Mineral Resources Extracting Economy
}

\author{
Elena Dotsenko, ${ }^{1, *}$, Natalya Ezdina $^{1}$, Angelina Prilepskaya ${ }^{2}$, and Kirill Pivnyk ${ }^{3}$ \\ ${ }^{1}$ Russian University of Economics, Department of Political Economy and History of Economic \\ Science, 117997, Moscow, 36 Stremyanny lane, Russia \\ ${ }^{2}$ Russian University of Economics, Foreign Languages Chair No.2, 117997, Moscow, 36 Stremyanny \\ lane, Russia \\ ${ }^{3}$ ZAO Comenergo, 127591, Moscow, 77 Dubninskaya Street, Russia
}

\begin{abstract}
The immaturity of strategic and conceptual documents in the sphere of sustainable development of the Russian economy had a negative impact on long-term strategic forecasting of its neo-industrialization. At the present stage, the problems of overcoming the mineral and raw material dependence, the negative structural shift of the Russian economy, the acceleration of the rates of economic growth, the reduction of technological gap from the developed countries become strategically in demand. The modern structure of the Russian economy, developed within the framework of the proposed market model, does not generate a sustainable type of development. It became obvious that in conditions of the market processes' entropy, without neo-industrial changes, the reconstruction of industry on a new convergence-technological basis and without increasing the share of high technology production the instability of macroeconomic system, the risks of environmental and economic security of Russia are growing. Therefore, today we need a transition from forming one industry development strategy to the national one that will take into account both the social and economic and environmental challenges facing Russia as a mineral resources extracting country.
\end{abstract}

\section{Introduction}

The strategy of sustainable development is considered to be the program of long-term changes in the structure of the Russian economy, integrating the mechanism of interaction between the state, business, ecologically significant subjects of the economy and the population. The implementation of the sustainable development strategy should include a number of steps that must be followed by certain strategic directions - the components of Russia's social and economic development associated with the neoindustrialization of the country's economy.

\section{Materials and Methods}

*Corresponding author: ktyf110372@rambler.ru 
Delaying of sustainable development problem's solving in Russia forced the discussions among domestic and foreign researches. These discussions concern mining technologies development [1-5], creating basis of economic growth and improving socio-economic situation [6-9], finding new possibilities of lowering the pressure of mineral resource extraction on environment [10-16]. As a result of these discussions the new strategy of sustainable development must receive its fundamental bases.

The stages of programming and implementation of sustainable development strategy include the following:

At the first stage, the implementation of the sustainable development strategy should completely change the raw material production of the 4th technological mode. This implies the automation and robotization of coal, oil and gas, metal ores extraction and an increase in labor productivity in these industries by 1.5-2 times (up to the level of the US and EU companies), the transfer of these industries to the full cycle of production of modern products of organic chemistry, modern alloys and carbon plastics, full supply of the latest materials of domestic engineering, construction industry. Technological base of the first stage should become available technological platforms, and investors - high-tech holdings. With regard to strategic changes in the structure of property relations and institutions, at the first stage, the state needs to initiate vertical integration of the subjects of the raw, processing and sectoral sectors, legislatively establish the most attractive conditions for investing innovations that increase the technological level of raw material extraction and processing, creating conditions for the start of environmentally friendly production.

At the second stage, it is necessary to ensure the modernization of the processing enterprises of the 5th technological mode: auto, aircraft, shipbuilding, and energy. It is these sectors that should ensure the improvement of the ecological level of deep processing of raw materials (the 4th technological mode), which will expand the scope of application of environmentally friendly technologies and enhance their international competitiveness. We believe that it is impossible to do without imports of modern environmentally friendly technologies and their adaptation in existing technological platforms and innovative clusters, with investment support for existing in Russia commodity holdings, state guarantees and insurance. That is, the role of the state at the second stage is to stimulate the transition from the export of raw materials to its processing, large-scale investment of environmentally friendly technologies in innovative clusters, and the formation of a powerful environmental lobby.

At the third stage, the development of the 6th technological mode processes is connected with convergent technologies and the emergence of new industries, in which generated environmental innovations can find demand in the raw and processing industries. These are such convergent branches of the 6th technological mode as bioenergy and the production of environmentally friendly fuel, industrial distributed computing programming, and nanomaterial engineering. The technological basis of the third stage should be formed on a cross-platform principle, in network clusters, with large-scale government support. The state at the third stage of implementation of the neo-industrial strategy should concentrate on the development of inter-cluster and cross-platform interactions, maximum benefits and investment in the development and implementation of environmentally friendly technologies, in the creation of network clusters for the production of environmentally friendly materials.

It should be noted that, without government support, high risks of investing in R \& D and industries in the sphere of environmentally friendly technologies discourage large Russian and international investors. At the same time, in Russia there is no real support for the neo-industrial maneuver necessary for sustainable development either in the industrial sector or in the strategic documents of the Government. The share of high-tech products of the 6 th technological mode in gross Russian exports does not exceed 1.5\%, while the share of 
innovative enterprises is below $10 \%$. The task of creating 25 million high-tech jobs by 2020 and a general increase in labor productivity in one and a half times that of 2010 (due to the growth of investments and technological renewal of industry, state support for R \& D and the upgrading of employees' skills) is a demonstration of ambitions that are not backed by any strategic documents. Therefore, if in 2012 the share of products of the 6th technological mode was about $5 \%$ in the US GDP, in Russia it was $0.3 \%$, which corresponds to the contribution of fundamental science to the production of the final product of civil industries.

\section{Results and Discussion}

In order for the structural transformation of the Russian economy to take place in the form of neo-industrialization, rather than the consolidation of raw material specialization, it is necessary to develop a strategic union of the state and business. Today, they cannot separately initiate the sustainable development, because the state does not have corresponding institutions that determine the conditions for the inter-sectoral redistribution of financial, labor, intellectual, production resources. In turn, Russian business does not show interest in mass investment in environmentally friendly technologies.

Therefore, the neo-industrial strategic union is understood, first of all, as an institutional solution to the problem of interaction between business and the state, that is, as a definite long-term plan. On the other hand, such an alliance is a combination of forms of interaction between the state and business - integration, investment, credit, emission, and social. The following strategic directions of the structural policy of sustainable development can be identified:

1. The emphasis on the use of basic (natural, energy, accumulated intellectual capital and educational level of the population) and domestic (funds of the state budget and extrabudgetary funds, capital of investors and banks, market potential of special economic zones, technological parks, interregional sales networks), but not external resources (funds of international funds, foreign capital, international marketing). This means involving the financial capital of the banking system, the stock market, the largest national corporations in the process of investing innovations, manufacturing the products of the 6th technological mode industries for the domestic market and its promotion abroad, by creating appropriate tax, credit incentives for the state, promoting the integration of R \& D and high-tech processing, and also raw material productions, by using the market potential of IT, biochemical, nuclear-energy clusters.

2. Replacing the established after the "return of the state" in the 2000s term of long-term effectiveness of Russian business "participation in authority" on "participation in innovation". To do this, it is necessary to actively apply neo-dirigisme that is the full-scale use of indirect economic regulators by the state, not only in the financial sphere (in the sense of monetarists), but also to stimulate the inter-sectoral flow of investment, labor, intellectual capital, technology transfer, the development of regional clusters of productions 6th technological mode and small innovative entrepreneurship. To do this, it is important, first of all, to create the required institutional environment, which includes both state institutions that fully encourage innovation and the priority of breakthrough technologies in state support of industry, as well as business institutions that can reduce its transaction costs when investing innovations.

3. The creation of long-term conditions for sustainable growth of wellbeing in the process of formation of environmentally friendly production in processing industries on a new technological basis, and active support of the state for environmental entrepreneurship. As a key, long-term goal of structural reforms in the Russian economy, the growth of wellbeing is impossible without reducing the number of loss-making industrial enterprises (by 2014 up to $40 \%$ ), expanding employment in manufacturing and high-tech industries. At the same 
time, raw materials extraction remains the most profitable type of business in the Russian industry. The narrow layer of innovative firms is unstable, and most of these business entities - enterprises, banks, and venture funds - are in fact not engaged in innovations, but import of finished products and shallow processing of raw materials, violating the ecological balance.

Therefore, the union of the state and business, aimed at changing the most stable elements of the structure of the national economy - formal and informal institutions, means of production, mechanisms for inter-sectoral and inter-regional distribution of factors of production and resources - should become the first step towards sustainable development in the process of neo-industrial structural transformations. That is, by influencing on the most stable elements of the structure of the national economy, the state can initiate a reduction of obstacles to sustainable development by stimulating innovative activity in manufacturing industries, involving large businesses in investing innovations. To do this, it is important to develop legislation concerning public-private partnerships, high-tech holdings, tax incentives, government loans and guarantees for innovative firms, to initiate a neo-industrial lobby. This will give impetus to the change in technological, cluster structure, due to redistribution of resources between environmentally hazardous and safe production, between raw materials and innovative clusters.

4. The development of own scientific potential, import and adaptation of nature-saving technologies instead of import of production equipment. It is necessary to take into account the experience of Argentina in the implementation of the strategy of "neo-nationalism" (comprehensive support of the national industry and domestic investors). Due to the fact that after the economic crisis in the late 1990s, the manufacturing industry was developing at a faster pace, the Argentine economy experienced a positive structural shift (the share of the modern 5th technological mode in 1997-2007 increased from 15 to $35 \%$ of GDP). This was preceded by a five-year economic policy of the state, including the return of the natural rent to the state, the creation of state-owned scientific and industrial enterprises (mainly in agriculture), large tax breaks to R \& D organizations, partial control over raw materials prices, the use of state investments to increase the capitalization of the largest manufacturing companies, transfer of the latest technologies as a prerequisite for multinational corporations' foreign direct investment. As a result, Argentina overcame the dominance of agriculture and became one of the industrial countries that came close to the beginning of sustainable development.

Realization of the potential for sustainable development of the Russian economy is impossible without the development of technological platforms and public-private partnerships in innovative clusters. Public-private partnerships in Russia play the role of attracting business entities to maintenance, operation, reconstruction, modernization or new construction of public infrastructure facilities on terms of sharing risks and responsibilities. But the state does not take responsibility for fulfilling the main condition of sustainable development - changing the institutional and reproductive structure of the economy in such a way as to ensure a massive inflow of investments in environmentally friendly technologies and speed up the replacement of existing production facilities with new ones that take into account the growing requirements of environmental safety.

Neo-industrial structural transformations require an early overcoming of the existing disintegration of science, production and finance in the conditions of reforms. Today, scientific institutions, small innovative enterprises, development companies practically have neither a financial base nor an opportunity to produce an innovative product, since their connections with large industrial enterprises were not established during the reform period.

Considering this, for the development of resource-technical and technological factors of sustainable development of the Russian economy, the following tools can be offered: 
1. Neo-industrial state order, which should become a means of changing the trajectory of the development of relations between innovation and production business and the state towards sustainable development. We understand it as the development of market demand for environment friendly technologies, means of production and ready-to-introduce technologies for environmental protection by the state. The economic mechanism of such state order should consist of three parts:

a) an order for R \& D projects on environmentally friendly technologies in the framework of the appropriate sustainable development strategy, which the Russian government should adopt;

b) an order for the production of products capable of reducing environmental damage from the activities of extractive enterprises dominating in the Russian industry;

c) state guarantees and state export crediting not less than $15 \%$ of environmentally friendly technologies produced within the framework of the neo-industrial state order, which should serve as a guarantee of their high international competitiveness.

As a promising organizational form of neo-industrial state order, a public-private partnership is considered. Within it an investment fund and venture capital funds, specialized tax and customs privileges should be formed.

2. Selective investment support for innovative projects of environmental-friendly technologies. When examining them, it is necessary to take into account the technological level of the replaced products, in order to concentrate government investments on the most promising for sustainable development of the Russian economy projects. To do this, it is proposed to classify enterprises - potential beneficiaries of state investments, in the following way: users of foreign technologies (not implementing the full cycle of R \& D), converters of environmental technologies (adapting them to Russian production conditions using their own scientific capabilities), effective innovators (using R \& D sporadically for individual projects) and breakthrough innovators, for which the creation of environmentally friendly technologies is the main factor of competitiveness.

For the least developed in Russia manufacturing and high-tech industries, such as radio electronics, instrument making, computer building, production of ultra-light and superstrong materials, microelectronics, robotics (in which the share of imports reaches 95$100 \%$ ), it is advisable to provide the state orders and state investments both to breakthrough and effective innovators, as well as to the firms-converters of environmentally friendly technologies.

In turn, in industries with $60-80 \%$ import share (chemistry of semiconductors, aircraft construction, electro-instrument engineering, machine-tool building, satellite engineering, etc.), the investment state support is appropriate for efficient and breakthrough innovators. Finally, for industries with an import share of 40-60\% (organic chemistry, vehicles), the state order and state investments are needed only for breakthrough innovators.

3. The import of environmentally friendly technologies and highly qualified specialists, which should eventually replace the import of the finished product. Along with this, it should be emphasized that there is a need for a comprehensive use of investment, organizational, institutional, financial and credit instruments of structural transformation of the Russian economy for the development of non-industrial import substitution in it.

\section{Conclusion}

The mechanism of development of neo-industrial structural transformations in the Russian economy aiming to enter the way of sustainable development reflects a multiplicative effect. It consists in the consistent modernization of the extractive and processing industries based on environmentally friendly technologies, in systematic interaction between the state and business in the development of the necessary institutions, in the formation of a neo- 
industrial state order, involving technological platforms and innovation clusters, implementing interest rate policies, state guarantees and investments.

\section{References}

1. A.A. Khoreshok, L.E. Mametyev, A.Y. Borisov, A.V. Vorobyev, IOP Conf. Ser.: Mater. Sci. Eng., 127:1, 012014 (2016)

2. A.B. Efremenkov, A.A. Khoreshok, S.A. Zhironkin, A.V. Myaskov, IOP Conf. Ser.: Earth Environ. Sci., 50:1, 012009 (2017)

3. A.A. Khoreshok, L.E. Mametyev, A.Y. Borisov, A.V. Vorobyev, IOP Conf. Ser.: Mater. Sci. Eng., 127:1, 012039 (2016)

4. M.A. Tyulenev, S.A. Zhironkin, O.I. Litvin, E.A. Tyuleneva, O.V. Zhironkina, S.O. Markov, Geotech. Geol. Eng. 35:5, 2065-2077 (2017)

5. S. Zhironkin, M. Gasanov, G. Barysheva, K. Kolotov, O. Zhironkina, E3S Web of Conf., 15, 03012 (2017)

6. S.A. Zhironkin, Ugol', 4, 47-49 (2002)

7. S.A. Zhironkin, Ugol', 6, 62-63 (2001)

8. V. Trifonov, O. Loyko, D. Nesteruk, S. Zhironkin, E. Strekovtsova, AIP Conf. Proceed., 1800, 050009 (2017)

9. E.A. Gasanov, M.A. Gasanov, Economics and Innovation Management, 1, 30-38 (2017) DOI: 10.26730/2587-5574-2017-1-30-38

10. N.N. Golofastova, V.G. Mikhailov, I.V., Seredyuk I.V. Economics and Innovation Management, 1, 66-75 (2017) DOI: 10.26730/2587-5574-2017-1-66-75

11. A.V. Myaskov, A.S. Ilyin, S.M. Popov, Gornyi Zhurnal, 2, 51-56 (2017)

12. O. Erdem, T. Güyagüler, N. Demirel, J. Sout. Afr. Inst. Min. Met., 112:5, 405-412 (2012)

13. A. Balabanova, V. Balabanov, E. Dotsenko, N. Ezdina, E3S Web of Conf., 15, 04013 (2017)

14. S.A. Zhironkin, K.A. Kolotov, O.V. Zhironkina, Economics and Innovation Management, 1, 4-16 (2017) DOI: 10.26730/2587-5574-2017-1-4-16

15. Z. Jurkasová, M. Cehlár, S. Khouri, Int. Conf. on Engin. Sci. and Prod. Man., ESPM, 409-412 (2015)

16. T.V. Kiseleva, V.G. Mikhailov, V.A. Karasev, IOP Conf. Ser.: Earth Environ. Sci., 45:1, 012013 (2016) 